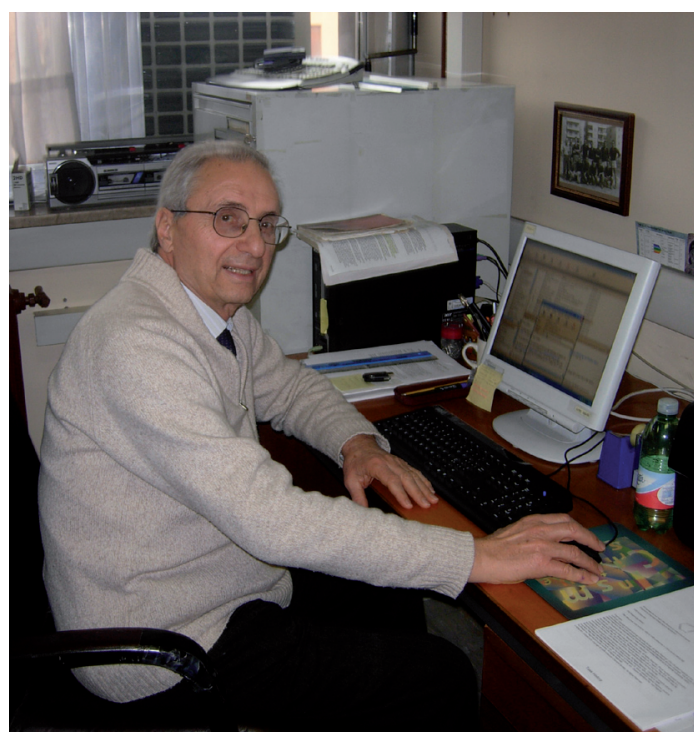

\section{Dedication to Professor Claudio Ercolani on the Occasion of his $\mathbf{7 5}^{\text {th }}$ Birthday}

Dear Reader!

This issue of the journal Macroheterocycles contains several papers dedicated to Professor Claudio Ercolani - member of the International Advisory Board of Macroheterocycles - on the occasion of his $75^{\text {th }}$ birthday. Professor Ercolani belongs to pioneers in the research of phthalocyanine complexes - his first paper on iron phthalocyanine was published in 1963 . We, all colleagues and friends of Professor Claudio Ercolani, congratulate him with this glorious Anniversary, and wish him a healthy and long life with his wife Graziella and many further successful years in research of phthalocyanines and their analogues.

\section{Scientific Career}

Prof. Claudio Ercolani received his Doctor Degree in Chemistry at the University of Rome "La Sapienza" in 1960. He was a postdoctoral fellow at the same University in 1961, at Manchester University (England) in 1964, and Research Associate at Florida State University (Tallahassee, Flo) in 1967-68. Since 1961 he started and developed his career, as Researcher, at the Italian Research National Council (CNR) and, while directing a research group, he was appointed the top position of "Research Director" (1974), kept until 1985. He got the "Libera Docenza" in 1969, and for many years was also Assistant Professor at the University "La Sapienza". In 1985, after resigning from the CNR, he became Associate and then Full Professor at the same University, where he worked until his retirement (October 2008).

Professor Ercolani spent several working periods in England, Germany, United States, and Australia, and was invited lecturer in Europe, United States, Canada, Russia, and in many universities in Italy. In 1992, he was component of a University Committee and visited China (Peking) for the definition of the planned exchange programs between the University of Rome "La Sapienza" and several Chinese Universities. He was the organizer of microsymposia and lecturer at the ICPP-1 (International Conference on Porphyrins and Phthalocyanines; Dijon, 2000) and ICPP-3 (New Orleans, 2004) and was invited to give a plenary lecture at the ICPP-4 (Rome, July, 2006). Since the 1970's, he was active participant to the International Congresses on Coordination Chemistry (ICCC) several times. In the nineties, he was "pro vice-Chancellor" for the Scientific Research at the University of "La Sapienza" and was the main responsible person for the organization of the University Congress of Rome for the triennial activity of the same University for the period 1988-91.
Since the 1960's Prof. Ercolani was a member of the Italian Chemical Society and of the Royal Society of Chemistry and is presently member of Society of Porphyrins and Phthalocyanines (SPP).

\section{Research Activity}

Professor Ercolani has published more than 120 scientific works including 8 book chapters and review articles. ${ }^{[1-8]}$ Among other research items, he has developed especially intense and successful scientific activity and published 90 research articles in the field of tetrapyrrolic macrocycles, devoting his attention to:

1) Synthesis and characterization of new monophthalocyanine complexes. ${ }^{[9-14]}$

2) Interaction of metal phthalocyanines with small molecules $\left(\mathrm{NO}, \mathrm{CO}, \mathrm{O}_{2}\right.$ ) and $\mathrm{N}$-bases..$^{[15-31]}$

3) Dioxygen activation, oxygen atom transfer, and oxidative catalysis. ${ }^{[28-31]}$

4) Synthesis and investigation of the molecular and electronic structure of single-atom bridged homo- and heterobimetallic $\mu$-oxodiiron(III) bisphthalocyaninates; ${ }^{[32-}$ ${ }^{43]}$ as well as $\mu$-nitrido ${ }^{[4-51]}$ and $\mu$-carbido ${ }^{[52-53]}$ complexes of general formula (L)M-X-M'( $\left.\mathrm{L}^{\prime}\right)(\mathrm{X}=\mathrm{O}, \mathrm{N}, \mathrm{C}$; L and L' phthalocyanine or porphyrin dianions) containing iron in high-valence states $\left(\mathrm{Fe}^{\mathrm{IV}}\right)$.

6) Bis(phthalocyanine) monometallic molecules (sandwich-type molecules) $\left[(\mathrm{Pc})_{2} \mathrm{M}\right] .^{[54-59]}$

7) Magnetic and electrical conductivity properties of metal-metal bonded ruthenium- and osmium phthalocyanine dimers $[(\mathrm{Pc}) \mathrm{M}]_{2} \cdot{ }^{[60,61]}$

8) Monodimensionally aligned metal phthalocyanine aggregates with conductivity properties. ${ }^{[62,63]}$

9) In more recent times (1996-2008) the scientific activity of Prof. Ercolani has shifted to the synthesis and 
investigation of the structural and electronic properties and examination of possible applicative aspects of novel classes of heterocyclic phthalocyanine analogues - porphyrazines with fused highly electron-withdrawing aromatic heterocycles: 1,2,5-thiadiazoloporphyrazines, ${ }^{[64-74]} \quad$ 1,2,5-selenodiazolo porphyrazines, ${ }^{[64,72,75,76]}$ 1,4-diazepinoporphyrazines, ${ }^{[77-79]}$ and pyrazinoporphyrazines with pyridyl rings ${ }^{[80-95]}$ or other peripheral substituents. ${ }^{[96-97]}$ This research field has been reach of fruitful results also contributed at national (C. Rizzoli, Parma; M. Meneghetti, Padova; R. Rosa and G. Ricciardi, Potenza) and international level (K. M. Kadish, Houston, Texas; P. Stuzhin, Ivanovo, Russia).

Moreover one of the most promising aspects of actual interest is the behaviour of these porphyrazine systems as photosensitizers for the generation of singlet oxygen, ${ }^{1} \mathrm{O}_{2}$, the main cytotoxic agent active in photodynamic therapy (PDT), but also the possibility of some of them to be used as bimodal or multimodal anticancer agents.

Prof. Ercolani published his papers almost exclusively in journals of high international level and he is still very active in research, as testified by the most recent publications.

\section{List of Collaborators}

\section{Present Research Group}

Dr. Donzello Maria Pia

Prof. Giuliano Moretti

Prof. Fabrizio Monacelli

Dr. Elisa Viola (Post Doc)

Dr. Piera Moro (PhD student)

Dr. Giorgia De Mori (PhD student)

Dr. Daniela Vittori (PhD student)

\section{International and National Collaborations}

- $\quad$ Prof. K. M. Kadish (University of Houston, Texas, USA).

- Prof. P. A. Stuzhin (Ivanovo State University of Chemistry and Technology, Russia)

- $\quad$ Prof. K. Awaga (University of Nagoya, Japan)

- Profs. A. Rosa and G. Ricciardi (University of Basilicata, Italy)

- $\quad$ Prof. C. Rizzoli (University of Parma, Italy)

- Prof. U. Russo (University of Padova, Italy)

- Prof. V. L. Goedken (University of Tallahassee, Flo, USA)

- Italian Research National Council (CNR)
Dr. Gianna Pennesi
Dr. Gentilina Rossi
Dr. Anna Maria Paoletti
Dr. Aldo Capobianchi
Dr. Elvira Maria Bauer

\section{Degree and PhD Students}

\section{Degree Students}

Giuseppe Trigiante
Lucia Cellucci
Maria Pia Donzello
Federica Scannerini

Sara Moraschi
Laura Bartolino
Elvira Maria Bauer

Silvia Angeloni

Demetria Cardarilli

Rita Agostinetto

Giulia Andreis

Francesca Vitali

Michela Fraschetti

Massimiliano Manni

\section{PhD students}

Elvira Maria Bauer

Costanza Bergami

Elisa Viola

Pera Moro

Giorgia De Mori

Daniela Vittori

\section{Publications on Phthalocyanines and Their Analogues}

Reviews and Books

1. Ercolani C., Floris B. Metal Phthalocyanine Single-Atom Bridged Dimers. In: Phthalocyanines: Properties and Applications. VCH Publ., New York, 1992, Vol. 2, pp. 1-43.

2. Ercolani C., Floris B. Metal Phthalocyanine Single-Atom Bridged Dimers. Part II. Recent Results. In: Phthalocyanines: Properties and Applications. VCH Publ., New York, 1995, Vol. 4, pp. 405-426.

3. Stuzhin P.A., Ercolani C. Porphyrazines with Annulated Heterocycles. In: The Porphyrin Handbook (Kadish K.M., Smith K.M., Guilard R., Eds.). Academic Press, New York, 2003, Vol. 15, pp. 263-365.

4. Floris B., Donzello M.P., Ercolani C. Single-Atom Bridged Dinuclear Metal Complexes with Emphasis on Phthalocyanine Systems. In: The Porphyrin Handbook. (Kadish K.M., Smith K.M., Guilard R., Eds.). Academic Press, New York, 2003, Vol. 18, pp.1-62.

5. Ercolani C. Diphthalocyanine Metal Complexes and Their Analogues (Overview). J. Porphyrins Phthalocyanines 2000, 4, 340 .

6. Angeloni S., Ercolani C. New Classes of Porphyrazine Macrocycles with Annulated Heterocyclic Rings (Microreview). J. Porphyrins Phthalocyanines 2000, 4, 474.

7. Donzello M.P., Ercolani C., Stuzhin P.A. Novel Families of Phthalocyanine-like Macrocycles - Porphyrazines with Annulated Strongly Electron-withdrawing 1,2,5-Thia/ selenodiazole Rings. Coord. Chem. Rev. 2006, 250, 15301561.

8. Donzello M.P.; Ercolani C. La Terapia Fotodinamica nel Contesto delle Cure Antitumorali. SAPERE 2011, in press.

\section{Synthesis and Structural Characterization of Monophthalocyaninates}

9. Ercolani C. Synthesis and Structure of Chromium(II)phthalocyanine ( $\beta$-form). Ric. Sci. 1966, 36, 975.

10. Ercolani C., Neri C., Porta P. Synthesis and X-ray Data of a Stable in Air Crystalline Modification of Chromium(II)phthalocyanine (Cr- $\alpha-\mathrm{Pc})$. Inorg. Chim. Acta, I 1967, 415.

11. Goedken V.L., Dessy G., Ercolani C., Fares V., Gastaldi L. Synthesis, Reactivity, and X-ray Crystal Structure of Dichloro(phthalocyaninato)titanium(IV). Inorg. Chem. 1985, 24, 991.

12. Scrocco M., Ercolani C., Paoletti A.M. Electron Energy Loss and X-Ray Photoelectron Spectra. Part 2. Phthalocyanine 


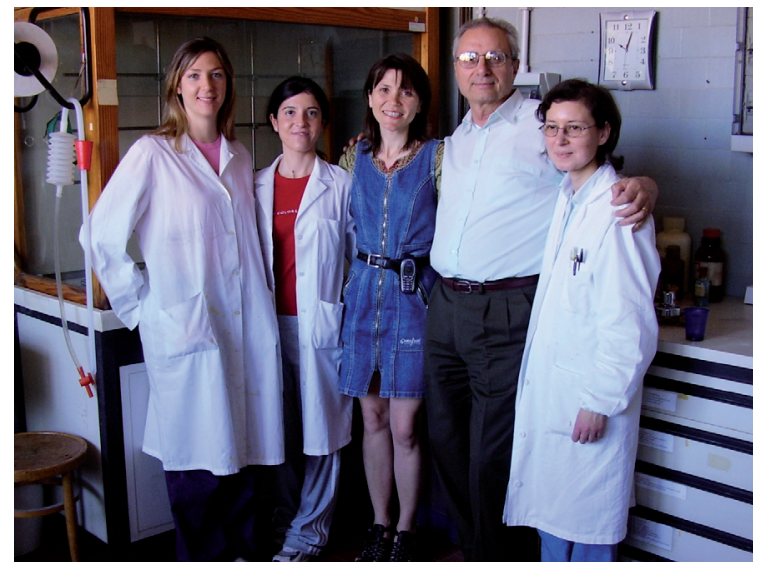

Prof. Claudio Ercolani in his lab with C. Bergami, E. Viola, L. Tomachinskaya and M.-P. Donzello

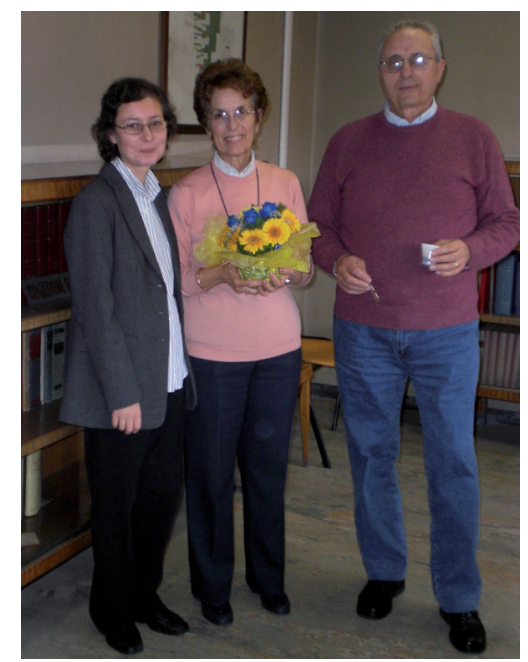

Prof. Ercolani with his wife Graziella and Dr. M.-P. Donzello (left)

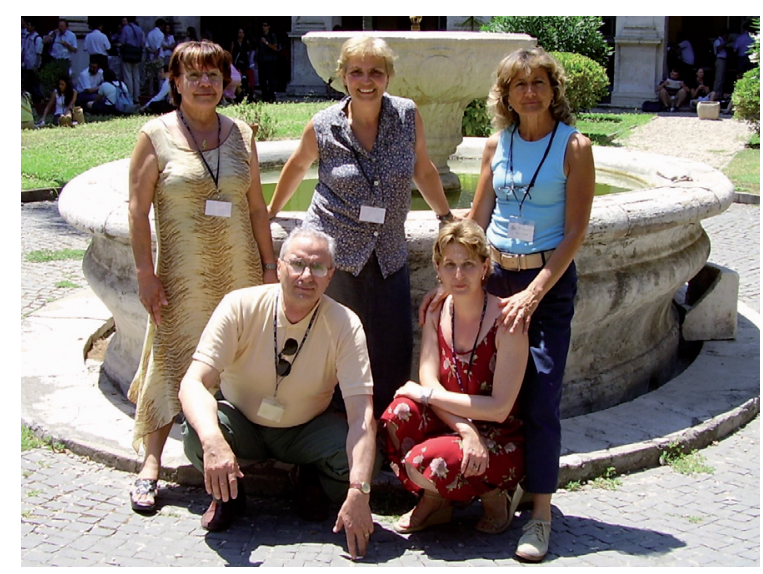

Prof. Ercolani with his colleagues from CNR at ICPP-4 (Rome, 2006): G. Rossi, A. M. Paoletti, G. Penessi, E. M. Bauer

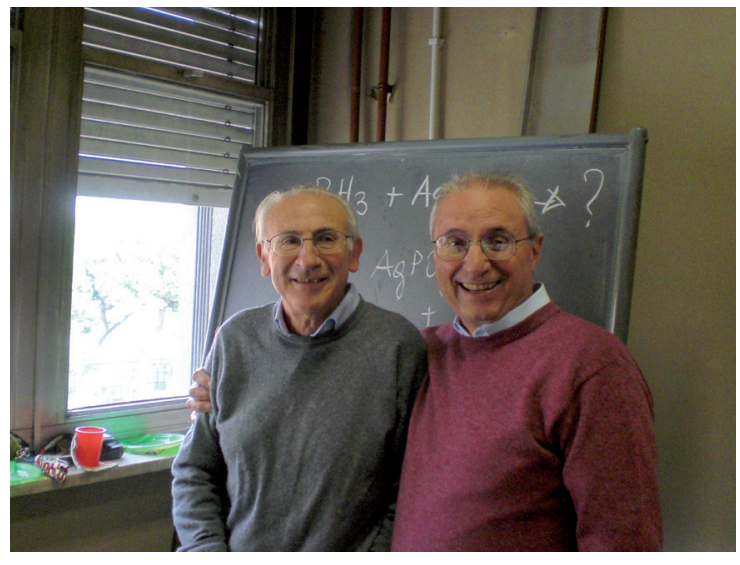

With his old friend and colleague Prof. Fabrizio Monacelli

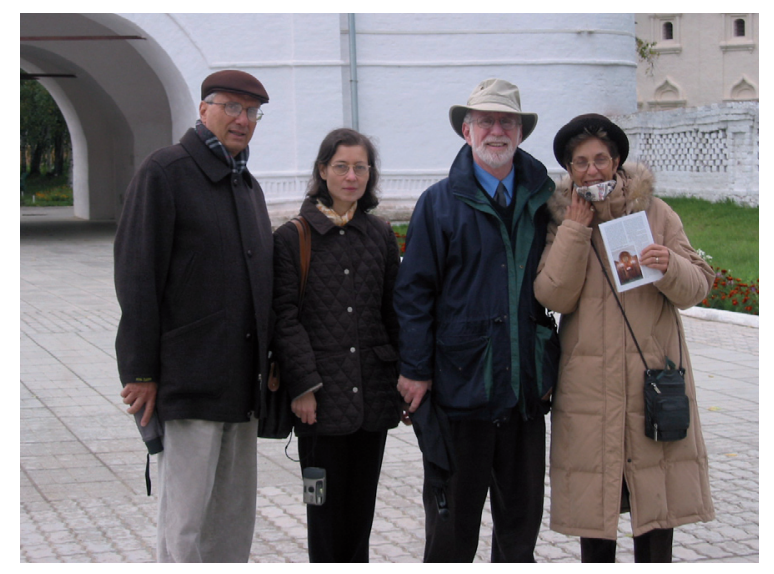

With Dr. M.-P.Donzello, Prof. K. Kadish and Graziella during IX International Conference on Chemistry of Porphyrins and Their Analogues (Suzdal', 2003)

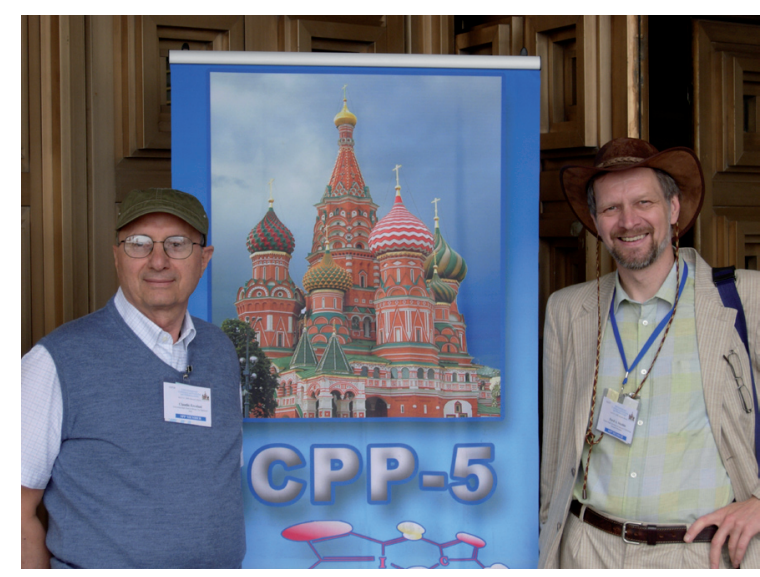

With Prof. Pavel Stuzhin at ICPP-5

(Moscow, 2008) 
and its $\mathrm{Ni}, \mathrm{Cu}$, and Co Derivatives in their $\alpha$-Form. J. Electr. Spectr. Relat. Phen. 1993, 155.

13. Cellucci L., Ercolani C., Lukes P.J., Chiesi-Villa A., Rizzoli C. Synthesis, X-ray Crystal Structure, and Reactivity of Dichloro(phthalocyaninato)niobium(IV) and Trichloro(phthalocyaninato)niobium(V). J. Porphyrins Phthalocyanines 1998, 1, 9.

14. Ballirano P., Caminiti R., Ercolani C., Maras A. X-ray Powder Diffraction Structure Reinvestigation of the $\alpha$ and $\beta$ Forms of Cobalt Phthalocyanine and Kinetics of the $\alpha \rightarrow \beta$ Phase Transition. J. Am. Chem. Soc. 1998, 120, 12798.

\section{Coordination and Catalytic Properties of Monophthalocyaninates}

15. Sartori G., Ercolani C. Assorbimento di NO su Fe ${ }^{\mathrm{II}}$-ftalocianina allo stato solido. Ric. Sci. 1963, 33, (II-A), 323.

16. Ercolani C., Neri C. Phthalocyanines of Metals of the First Transition Series. Part I. Nitrosyl Derivatives: Synthesis and Properties. J. Chem. Soc., A 1967, 1715.

17. Ercolani C., Neri C., Sartori G. Phthalocyanines of Metals of the First Transition Series. Part II. Influence of the Crystal Features on the Interaction with Nitric Oxide and on the M-(NO) Moiety. J. Chem. Soc., A 1968, 2123.

18. Collamati I., Ercolani C., Rossi G. Reversible Addition of $\mathrm{O}_{2}, \mathrm{NO}$, and $\mathrm{CO}$ to Phthalocyaninatoiron(II) in Concentrated Sulphuric Acid. Inorg. Nucl. Chem. Lett. 1976, 12, 799.

19. Ercolani C., Monacelli F., Rossi G. Interaction of Iron(II) Phthalocyanine with Molecular Oxygen in Concentrated Sulphuric Acid: Kinetics and Mechanism. Inorg. Chem. 1979, 18,712 .

20. Ercolani C., Monacelli F., Pennesi G., Rossi G., Antonini E., Ascenzi P., Brunori M. Equilibrium and Kinetic Study of the Reaction between Phthalocyaninatoiron(II) and Carbon Monoxide in Dimethyl Sulfoxide. J. Chem. Soc., Dalton Trans. 1981, 1120.

21. Pennesi G., Ercolani C., Ascenzi P., Brunori M. Equilibrium and Kinetic Study of Pyridine Binding to Phthalocyaninatoiron(II) in Dimethyl Sulfoxide. J. Chem. Soc., Dalton Trans. 1985, 1107.

22. Pennesi G., Ercolani C., Rossi G., Ascenzi P., Brunori M., Monacelli F. Equilibrium and Kinetic Study of the Reaction between Phthalocyaninatoiron(II) and Carbon Monoxide in Dimethyl Sulfoxide in the Presence of Pyridine. Evidence for the Presence of a Transient. J. Chem. Soc., Dalton Trans. $1985,1113$.

23. Ascenzi P., Brunori M., Pennesi G., Ercolani C., Monacelli F. Equilibrium and Kinetic Study of Nitric Oxide Binding to Phthalocyaninatoiron(II) in Dimethyl Sulfoxide. J. Chem. Soc., Dalton Trans. 1987, 369.

24. Ascenzi P., Brunori M., Pennesi G., Ercolani C., Monacelli F. Equilibrium and Kinetic Study of Imidazole Binding to Phthalocyaninatoiron(II) in Dimethyl Sulfoxide. J. Chem. Soc., Dalton Trans. 1990, 105.

25. Ascenzi P., Ercolani C., Monacelli F. Equilibrium and Kinetic Study of Piperidine Binding to Phthalocyaninatoiron(II) in Dimethyl Sulfoxide. Inorg. Chim. Acta 1994, 219, 199.

26. Ascenzi P., Fruttero R., Ercolani C., Monacelli F. Determination of Nitric Oxide Solubility in Different Solvents via the Reaction with Phthalocyaninatoiron(II). Analysis 1996, 24, 316.

27. Boffi A., Ercolani C., Monacelli F., Ascenzi P. Cyanide Binding to Phthalocyaninato-iron(II) in Dimethyl Sulfoxide in the Presence of Carbon Monoxide. Kinetic and Equilibrium Study. Inorg. Chim. Acta 1998, 267, 109.

28. Ercolani C., Pennesi G. Nitrosyl and Nitro Derivatives of Phthalocyaninatocobalt(II): Reactivity with Dioxygen and Oxygen Atom Transfer. Inorg. Chim. Acta 1985, 101, L41.
29. Ercolani C., Gardini M., Pennesi G., Rossi G. Dioxygen Activation and Catalytic Oxidation of Triphenylphosphine by Iron Phthalocyanine Compounds. J. Mol. Catal. 1985, 30, 135.

30. Ercolani C., Paoletti A.M., Pennesi G., Rossi G. Nitrosyl/ nitro Redox Couples with Metal Phthalocyanines: Synthesis and Characterization of Nitro Derivatives of Cobalt and Iron Phthalocyanine, Dioxygen Activation, Oxygen-Atom Transfer, and Stoichiometric and Catalytic Oxidation of Terminal Olefines. J. Chem. Soc., Dalton Trans. 1991, 1317.

31. Capobianchi A., Paoletti A.M., Pennesi G., Rossi G., Caminiti R., Ercolani C. Ruthenium Phthalocyanine: Structure, Magnetism, Electrical Conductivity Properties, and Role in Dioxygen Activation and Oxygen Atom Transfer to 1-Octene. Inorg. Chem. 1994, 33, 4635.

\section{Single-atom Bridged Binuclear Complexes}

32. Ercolani C., Monacelli F., Rossi G. Synthesis and Characterization of a $\mu$-Oxo Dimer Formed by the Interaction of Phthalocyaninatoiron(II) with Dioxygen. Inorg. Chim. Acta 1980, 44, L215.

33. Ercolani C., Gardini M., Pennesi G., Rossi G. Oxygen Atom Transfer in the Oxidation of Triphenylphosphine by $\mu$-Oxobis(phthalocyaninatoiron(III)). J. Chem. Soc., Chem. Comm. 1983, 549 .

34. Ercolani C., Rossi G., Monacelli F., Verzino M. Interaction of Phthalocyaninatoiron(II) with Molecular Oxygen. Kinetics and Mechanism of the Reaction in Dimethyl Sulfoxide. Inorg. Chim. Acta 1983, 73, 95.

35. Ercolani C., Gardini M., Monacelli F., Pennesi G., Rossi G. Interaction of Phthalocyaninatoiron(II) with Molecular Oxygen: Synthesis and Characterization of Two Different Crystalline Forms of $\mu$-Oxo-bis[phthalocyaninatoiron(III)]. Inorg. Chem. 1983, 22, 2584.

36. Bottomley L.A., Ercolani C., Gorce J.-Noel, Pennesi G., Rossi G. Spectroelectrochemistry of $\mu$-Oxоbis[phthalocyaninatoiron(III)]. Inorg. Chem. 1986, 25, 3972.

37. Ercolani C., Gardini M., Murray K.S., Pennesi G., Rossi G. Crystalline Isomerism in $\mu$-Oxo-bis[phthalocyaninatoiron(III)]: Further Characterization of the Isomer Having a Linear or Quasi-Linear Fe-O-Fe Bond System ( $\mu$-Oxo(2)). Inorg. Chem. 1986, 25, 3972.

38. Ercolani C., Gardini M., Murray K.S., Pennesi G., Rossi G., Zwack P. Molecular and Electronic Structure of Six-coordinate Low-spin Oxo-bridged Dimers Formed by the Interaction of $\mu$-Oxo-bis[phthalocyaninatoiron(III)] with Nitrogen Bases. Inorg. Chem. 1987, 26, 3539.

39. Ercolani C., Monacelli F., Dzugan S., Goedken V.L., Pennesi G., Rossi G. X-Ray Crystal Structure of $\mu$-Oxo-bis[(1methylimidazole)phthalocyaninatoiron(III)] and Comments on the Molecular Structure and Chemistry of Oxo-bridged Iron Phthalocyaninate Dimers. J. Chem. Soc., Dalton Trans. 1991, 1309.

40. Ercolani C., Monacelli F. Unequivocal Evidence about the Presence of $\mathrm{Fe}^{\mathrm{III}}$ in $\mu$-Oxo-bis(tetrakis(t-butyl) phthalocyaninatoiron). J. Porphyrins Phthalocyanines 2001, 5,668 .

41. Monacelli F., Ercolani C. A Reinterpretation of Experimental Data (Gas-volumetric Uptake of Dioxygen) against an Erroneous Formulation for $\mu$-Oxo-bis[tetra( $t$-butyl) phthalocyaninatoiron(III). Inorg. Chim. Acta 2003, 346C, 95.

42. Matassa R., Ballirano P., Donzello M.P., Ercolani C., Sadun C., Caminiti R. A Nanostructured Polymorph of $\mu$-Oxobis( phthalocyaninatoiron(III)) Studied by Angular and Energy Dispersive X-ray Diffraction Techniques. Nano 2007, 2, 121.

43. Donzello M.P., Bartolino L., Ercolani C., Rizzoli C. A Rare $\mu$-Hydroxo Bridged Species. Synthesis, Structure and 
Properties of $\mu$-Hydroxo(tetra-phenylporphyrinatomanganese(III))(phthalocyaninato(azido)chromium(III)), [(TPP) $\mathrm{Mn}-\mathrm{O}(\mathrm{H})-\mathrm{CrPc}\left(\mathrm{N}_{3}\right)$ ]. Inorg. Chem. 2006, 45, 6988.

44. Goedken V.L., Ercolani C. $\mu$-Nitrido-Bridged Iron Phthalocyanine Dimers: Synthesis and Characterization. J. Chem. Soc., Chem. Comm. 1984, 378.

45. Bottomley L.A., Gorce J.-Noel, Goedken V.L., Ercolani C. Spectroelectrochemistry of a $\mu$-Nitrido Bridged Iron Phthalocyanine Dimer. Inorg. Chem. 1985, 24, 3733.

46. Ercolani C., Gardini M., Pennesi G., Rossi G., Russo U., Zanonato P. High-Valent Iron Phthalocyanine Five- and SixCoordinated $\mu$-Nitrido Dimers. Inorg. Chem. 1988, 27, 422.

47. Rossi G., Gardini M., Pennesi G., Ercolani C., Goedken V.L. Ruthenium Phthalocyanine Chemistry: Synthesis and Properties of a Mixed-valence Nitrido-bridged Ruthenium Phthalocyanine Dimer. J. Chem. Soc., Dalton Trans. 1989, 193.

48. Ercolani C., Hewage S., Heucher R., Rossi G. First Example of a Mixed-Ligand Bimetallic (Fe-Fe) $N$-Bridged Dimer: $\mu$-Nitrido[(tetraphenylporphyrinatoiron)(phthalocyaninatoiron)]. Inorg. Chem. 1993, 32, 2975.

49. Ercolani C., Jubb J., Pennesi G., Russo U., Trigiante G. $\mu$-Nitrido[(tetraphenylporphyrinatoiron)(phthalocyaninatoiron)] and its $\mathrm{Fe}-\mathrm{Ru}$ Analogue: Redox Behaviour and Characterization of New $\mathrm{Fe}^{\mathrm{IV}}$ Containing Species. X-Ray Crystal Structure of [(THF) (TPP)Fe-N-FePc $\left.\left(\mathrm{H}_{2} \mathrm{O}\right)\right]\left(\mathrm{I}_{5}\right) \cdot 2 \mathrm{THF}$. Inorg. Chem. 1995, 34, 2535.

50. Donzello M.P., Ercolani C., Kadish K.M., Ou Z., Russo U. Synthesis, Chemical-Physical Characterization, and Redox Properties of a New Mixed-Ligand Heterobimetallic $N$-Bridged Dimer: ( $\mu$-Nitrido)[((tetraphenylporphyrinato)manganese) ((phthalocyaninato)iron)]. Inorg. Chem. 1998, 37, 3682.

51. Donzello M.P., Ercolani C., Russo U., Chiesi-Villa A., Rizzoli C. Metal- and Ligand Centred Monoelectronic Oxidation of $\mu$-Nitrido [(TPP)Mn-N-FePc]. X-Ray Crystal Structure of the $\mathrm{Fe}^{\mathrm{IV}}$-Containing Species [(THF)(TPP)Mn-N-FePc $\left(\mathrm{H}_{2} \mathrm{O}\right)$ ] (I $\mathrm{I}_{5}$ )2THF. Inorg. Chem. 2001, 40, 2963.

52. Rossi G., Goedken V.L., Ercolani C. $\mu$-Carbido Bridged Iron Phthalocyanine Dimers: Synthesis and Characterization. J. Chem. Soc., Chem. Comm. 1988, 46.

53. Ercolani C., Gardini M., Goedken V.L., Pennesi G., Rossi G., Russo U., Zanonato P. High-Valent Iron Phthalocyanine Fiveand Six-Coordinated $\mu$-Carbido Dimers. Inorg. Chem. 1989, $28,3097$.

\section{Sandwich-type Bisphthalocyaninates}

54. Ercolani C., Paoletti A.M., Pennesi G., Rossi G., ChiesiVilla A., Rizzoli C. Two Phthalocyanine Units "Stapled" by Carbon-Carbon $\sigma$ Bonds in a New Sandwich-type Molecule: $\left\{5,5^{\prime} ; 19,19^{\prime}\right.$ - [Bi(phthalocyaninato(2-)] $\}$ titanium(IV). Synthesis, X-ray Crystal Structure, and Properties. J. Chem. Soc., Dalton Trans. 1990, 1971.

55. Capobianchi A., Ercolani C., Paoletti A.M., Pennesi G., Rossi G., Chiesi-Villa A., Rizzoli C. Inter-Ligand C-C $\sigma$ Bonds Breaking and Repair in a "Stapled" Bis(phthalocyanine) Titanium Complex. Synthesis, Characterization, and Electrical Conductivity Properties of Oxidation Products of Bis(phthalocyaninato)Titanium(IV) and Bis(phthalocyaninato)Tin(IV). X-ray Crystal Structure of $\left[\mathrm{Pc}_{2} \mathrm{Ti}\right]\left(\mathrm{I}_{3}\right)_{0.66}$. Inorg. Chem. 1993, 32, 4605.

56. Scrocco M., Ercolani C., Paoletti A.M. Electron Energy Level Transitions in Bis(phthalocyaninato)titanium(IV) Examined by UV-visible, Near IR, EELS, and XPS Spectra. Inorg. Chem. 1996, 35, 4788.

57. Donzello M.P., Ercolani C., Lukes P.J. Bis(phthalocyaninato) niobium(IV): A New Sandwich-type Molecule "Stapled" by
Two Inter-ligand C-C $\sigma$ Bonds. Inorg. Chim. Acta 1997, 254, 171.

58. Donzello M.P., Ercolani C., Chiesi-Villa A., Rizzoli C. One Step forward to "Stapled" Bis(phthalocyanine) Metal Complexes: Synthesis, Characterization, and Redox Properties of Bis(phthalocyaninato)niobium(IV). X-Ray Crystal Structure of the Monoelectronically Oxidized Species $\left[\mathrm{Pc}_{2} \mathrm{Nb}\right]\left(\mathrm{I}_{3}\right)$ $\left(\mathrm{I}_{2}\right)_{0.5}(\mathrm{ClNP})_{3.5}(\mathrm{CINP}=1$-Chloronaphthalene $)$. Inorg. Chem. 1998, 37, 1347.

59. Bauer E.M., Donzello M.P., Ercolani C., Masetti E., Panero S., Ricciardi G., Rosa A., Chiesi-Villa A., Rizzoli C. "Stapled" Bis(phthalocyaninato)niobium(IV), $\mathrm{Pc}_{2} \mathrm{Nb}$ : X-Ray Crystal Structure, Chemical and Electrochemical Behaviour, and Theoretical Studies. Perspectives for the Use of $\mathrm{Pc}_{2} \mathrm{Nb}$ (Thin Films) as an "Optically Passive Electrode" in Electrochromic Devices. Inorg. Chem. 2003, 42, 283.

\section{Metal-metal Bonded Phthalocyanine Dimers}

60. Caminiti R., Donzello M.P., Ercolani C., Sadun C. Dimeric Osmium Phthalocyanine Organized in Discrete Columnarly Stacked Assemblies: Structure, Magnetism, and Electrical Conductivity Properties. Inorg. Chem. 1998, 37, 4210.

61. Caminiti R., Donzello M.P., Ercolani C., Sadun C. Further Structural Information on the Intra- and Interunit Contacts in Dimeric Ruthenium Phthalocyanine. Inorg. Chem. 1999, 38, 3027.

\section{Monodimensionally Aligned Metal Phthalocyanine Aggregates with Conductivity Properties}

62. Paoletti A.M., Pennesi G., Rossi G., Ercolani C. A New Approach to Cofacially Assembled Partially Oxidized Metal Phthalocyanine Low Dimensional Solids: Synthesis, Structure, and Electrical Conductivity Properties of the $\mathrm{Fe}^{\mathrm{IV}}$ Containing Species $\left[(\mathrm{PcFe})_{2} \mathrm{C}\right]\left(\mathrm{I}_{3}\right)_{0.66}$ Obtained by $\mathrm{I}_{2}$ Doping of $\mu$-Carbidobis[phthalocyaninatoiron(IV)]. Inorg. Chem. 1995, 34, 4780.

63. Capobianchi A., Pennesi G., Paoletti A.M., Rossi G., Caminiti R., Sadun C., Ercolani C. Ruthenium Phthalocyanine and its Reaction with Dioxygen. Synthesis, Structure, Magnetism, and Electrical Conductivity Properties of the Cofacially Assembled Ruthenoxane Aggregate of Formula HO-[(Pc) $\mathrm{RuO}$ ]-OH (Average $\mathrm{n}=11$ ). Inorg. Chem. 1996, 35, 4643.

\section{Heterocyclic Analogues of Phthalocyanines}

64. Ercolani C., Stuzhin P., Donzello M.P., Bauer E.M., Cardarilli D., Agostinetto R. New Types of Porphyrazine Macrocycles and Their Metal Derivatives, and Procedure for Their Preparation. Patent, No. RM97A000577 (24/09/97).

65. Stuzhin P.A., Bauer E.M., Ercolani C. Tetrakis(thiadiazole) porphyrazines. 1. Synthesis and Properties of Tetrakis(thiadiazole)porphyrazine and its Magnesium and Copper Derivatives. Inorg. Chem. 1998, 37, 1533.

66. Bauer E.M., Cardarilli D., Ercolani C., Stuzhin P.A., Russo U. Tetrakis(thiadiazole)porphyrazines. 2. Metal Complexes with $\mathrm{Mn}^{\mathrm{II}}, \mathrm{Fe}^{\mathrm{II}}, \mathrm{Co}^{\mathrm{II}}, \mathrm{Ni}^{\mathrm{II}}$, and $\mathrm{Zn}^{\mathrm{II}}$. Inorg. Chem. 1999, 38, 6114.

67. Stuzhin P.A., Pozdysheva E.A., Mal'chugina O.V., Popkova I.A., Ercolani C. Tetrakis(thiadiazole)porphyrazines. Part 3. Study of Acid-base Properties and Stability of Tetrakis-3,4(1,2,5-thiadiazolo)porphyrazine in Sulfuric Acid Solution. Chem. Heteryclic Comp. 2005, 278 (Khim. Geterotsikl. Soed. 2005, 246).

68. Donzello M.P., Agostinetto R., Ivanova S.S., Fujimori M., Suzuki Y., Yoshikawa H., Awaga K., Ercolani C., Kadish K.M., Shen J., Stuzhin P.A. Tetrakis(thiadiazole)porphyrazines. 4. Direct Template Synthesis, Structure, 
General Physicochemical Behavior and Redox Properties of $\mathrm{Al}^{\mathrm{III}}, \mathrm{Ga}^{\mathrm{III}}$ and $\mathrm{In}^{\mathrm{III}}$ Complexes. Inorg. Chem. 2005, 44, 8539 .

69. Donzello M.P., Ercolani C., Kadish K.M., Ricciardi G., Rosa A., Stuzhin P.A. Tetrakis(thiadiazole)porphyrazines. 5. Electrochemical and DFT/TDDFT Studies of the Free-base Macrocycle and Its $\mathrm{Mg}^{\mathrm{II}}, \mathrm{Zn}^{\mathrm{II}}$ and $\mathrm{Cu}^{\mathrm{II}}$ Complexes. Inorg. Chem. 2007, 46, 4145.

70. Donzello M.P., Ercolani C., Kadish K.M., Ricciardi G., Rosa A. Tetrakis(thiadiazole)porphyrazines. 6. Spectroelectrochemical and DFT/TDDFT Studies of the Anions [TTDPzM] ${ }^{\mathrm{n}-}(\mathrm{n}=1-4$; $\left.\mathrm{M}=\mathrm{Zn}^{\mathrm{II}}, \mathrm{Mg}^{\mathrm{II}}\left(\mathrm{H}_{2} \mathrm{O}\right), \mathrm{Cu}^{\mathrm{II}}, 2 \mathrm{H}^{\mathrm{I}}\right)$. Inorg. Chem. 2009, 48, 9890.

71. Donzello M.P., Fujimori M., Yoshikawa H., Awaga K., Ercolani C. Tetrakis(thiadiazole)porphyrazines. 7. Synthesis, and Structure of $\mu$-Oxo-bis[tetrakis(thiadiazole)porphyrazinatoaluminum(III)]. J. Porphyrins Phthalocyanines 2010, 14, 343.

72. Kudrik E.V., Bauer E.M., Ercolani C., Stuzhin P.A., ChiesiVilla A., Rizzoli C. Unsymmetrical Porphyrazines with Annulated 1,2,5-Thiadiazole and 3,6-Diamyloxybenzene Rings: Synthesis, Characterization and X-ray Crystal Structure of $\mathrm{H}_{2}\left\{\mathrm{SN}_{2}\right\}\left\{3,6-(\mathrm{OAm})_{2} \mathrm{Bz}\right\}_{3} \mathrm{Pz}$. Mendeleev Commun. 2001, 45.

73. Donzello M.P., Ercolani C., Gaberkorn A., Kudrik E.V., Meneghetti M., Marcolongo G., Rizzoli C., Stuzhin P.A. Synthesis, X-ray Crystal Structure, UV-Visible Linear and Nonlinear (Optical Limiting) Spectral Properties of Symmetrical and Unsymmetrical Porphyrazines with Annulated 1,2,5-Thiadiazole and 3,6-Diamyloxybenzene Moieties. Chem. Eur. J. 2003, 9, 4009.

74. Gaberkorn A.A., Popkova I.A., Stuzhin P.A., Ercolani C. Study of Basic Propeties of tert-Butylsubstituted Tribenzo(1,2,5thiadiazolo)porphyrazines. Russ. J. Gen. Chem. 2006, 76, 1494.

75. Bauer E.M., Ercolani C., Galli P., Popkova I.A., Stuzhin P.A. Tetrakis(selenodiazole)porphyrazine. 1. Tetrakis(selenodiazole)porphyrazine and its $\mathrm{Mg}^{\mathrm{II}}$ and $\mathrm{Cu}^{\mathrm{II}}$ Derivatives. Evidence for Their Conversion to Tetrakis(pyrazino) porphyrazines through Octaminoporphyrazines. J. Porphyrins Phthalocyanines 1999, 3, 371.

76. Angeloni S., Bauer E.M., Ercolani C., Popkova I.A., Stuzhin P.A.Tetrakis(selenodiazole)porphyrazines. 2. MetalComplexes with $\mathrm{Mn}^{\mathrm{II}}, \mathrm{Co}^{\mathrm{II}}, \mathrm{Ni}^{\mathrm{II}}$, and $\mathrm{Zn}^{\mathrm{II}}$. J. Porphyrins Phthalocyanine 2001, 5, 881 .

77. Donzello M.P., Ercolani C., Stuzhin P.A., Chiesi-Villa A., Rizzoli C. Porphyrazines with Annulated Diazepine Rings. 1. Synthesis and Characterization of Tetrakis-2,3-(5,7-diphenyl$6 \mathrm{H}-1,4-$ diazepino)porphyrazine and Its $\mathrm{Mg}^{\mathrm{II}}, \mathrm{Cu}^{\mathrm{II}}$, and $\mathrm{Zn}^{\mathrm{II}}$ Complexes. X-ray Crystal Structure of 2,3-Dicyano-5,7diphenyl-6H-1,4-diazepine. Eur. J. Inorg. Chem. 1999, 2075.

78. Donzello M.P., Dini D., D'Arcangelo G., Zhan R., Ou Z., Ercolani C., Stuzhin P.A., Kadish K.M. Porphyrazines with Annulated Diazepine Rings. 2. An Alternative Synthetic Route to Tetrakis-2,3-(5,7-diphenyl-6H-1,4-diazepino)porphyrazines. New Metal Complexes, General Physicochemical Data, UV-Vis Linear and Optical Limiting Behaviour, Electrochemical and Spectroelectrochemical Properties. J. Am. Chem. Soc. 2003, 125, 14190.

79. Donzello M.P., Ercolani C., Viola E., Bubnova A., Khelevina O.G., Stuzhin P.A. Synthesis and Spectral Properties of Low-Symmetry Tri(benzo)mono(diazepino)porphyrazines. Tautomerism of the Annulated 1,4-Diazepine Ring. Aus. J. Chem. 2008, 61, 262.

80. Donzello M.P., Ou Z., Monacelli F., Ricciardi G., Rizzoli C., Ercolani C., Kadish K.M. Tetra-2,3-pyrazinoporphyrazines with Externally Appended Pyridine Rings. 1. Tetrakis-2,3[5,6-di(2-pyridyl)pyrazino]porphyrazine: a New Macrocycle with Remarkable Electron-Deficient Properties. Inorg. Chem. 2004, 43, 8626.

81. Donzello M.P., Ou Z., Dini D., Meneghetti M., Ercolani C., Kadish K.M. Tetra-2,3-pyrazinoporphyrazines with Externally Appended Pyridine Rings. 2. Metal Complexes of Tetrakis2,3-[5,6-di(2-piridyl)pyrazino]porphyrazine: Linear and Nonlinear Optical Properties and Electrochemical Behavior. Inorg. Chem. 2004, 43, 8637.

82. Bergami C., Donzello M.P., Ercolani C., Monacelli F., Rizzoli C. Tetra-2,3-pyrazinoporphyrazines with Externally Appended Pyridine Rings. 3. A New Highly Electron-Deficient Octacationic Macrocycle: Tetrakis-2,3-[5,6-di\{2-( $N$-methyl) pyridiniumyl $\}$ pyrazino]porphyrazine. Inorg. Chem. 2005, 44, 9852.

83. Bergami C., Donzello M.P., Monacelli F., Ercolani C., Kadish K.M. Tetra-2,3-pyrazinoporphyrazines with Externally Appended Pyridine Rings. 4. UV-visible and Electrochemical Evidence of the Remarkable Electron-Deficient Properties of the New Tetrakis-2,3-[5,6-di\{2-(N-methyl) pyridiniumyl $\}$ pyrazino]porphyrazinatometal Octacations, $\left[(2-\mathrm{Mepy})_{8} \mathrm{TPyzPzM}^{8+}\left(\mathrm{M}=\mathrm{Mg}^{\mathrm{II}}\left(\mathrm{H}_{2} \mathrm{O}\right), \mathrm{Co}^{\mathrm{II}}, \mathrm{Cu}^{\mathrm{II}}, \mathrm{Zn}^{\mathrm{II}}\right)\right.$. Inorg. Chem. 2005, 44, 9862.

84. Villano M., Amendola V., Sandonà G., Donzello M.P., Ercolani C., Meneghetti M. Excited States Dynamic and Nonlinear Absorption of a Pyrazinoporphyrazine Macrocycle Carrying Externally Appended Pyridine Rings. J. Phys. Chem. B 2006, 110, 24354.

85. Ercolani C., Monacelli F., Donzello M.P., Viola E. "Complessi mono- e pentametallici di tipo porfirazinico come fotosensibilizzatori in campo farmaceutico". Patent registered in Italy 29.10.07, $\mathrm{n}^{\circ} \mathrm{RM} 2007 \mathrm{~A} 000571$.

86. Donzello M.P., Viola E., Cai X., Mannina L., Rizzoli C., Ricciardi G., Ercolani C., Kadish K.M., Rosa A. Tetra-2,3pyrazinoporphyrazines with Externally Appended Pyridine Rings. 5. Synthesis, Physicochemical and Theoretical Studies of a Novel Pentanuclear Palladium(II) Complex and Related Mononuclear Species. Inorg. Chem. 2008, 47, 3903.

87. Donzello M.P., Viola E., Bergami C., Dini D., Ercolani C., Giustini M., Kadish K.M., Meneghetti M., Monacelli F., Rosa A., Ricciardi G. Tetra-2,3-pyrazinoporphyrazines with Externally Appended Pyridine Rings. 6. Chemical and Redox Properties and Highly Effective Photosensitizing Activity for Singlet Oxygen Production of Penta- and Monopalladated Complexes in Dimethylformamide Solution. Inorg. Chem. 2008, 47, 8757.

88. Viola E., Donzello M.P., Ciattini S., Portalone G., Ercolani C. Redox Chemistry of Tetrakis[5,6-di(2-pyridyl)-2,3-pyrazino] porphyrazinatocobalt(II): Isolation and Characterization of Solid Pure $\mathrm{Co}^{\mathrm{I}}, \mathrm{Co}^{\mathrm{II}}$, and $\mathrm{Co}^{\mathrm{III}}$ Complexes. Eur. J. Inorg. Chem. 2009, 1600

89. Cai X., Donzello M.P., Viola E., Rizzoli C., Ercolani C., Kadish K.M. Structural, UV-Visible and Electrochemical Studies on 2,3-Dicyano-5,6-di(2-pyridyl)pyrazine, [(CN) $\left.{ }_{2} \mathrm{Py}_{2} \mathrm{Pyz}\right]$, its Complexes $\left[(\mathrm{CN})_{2} \mathrm{Py}_{2} \mathrm{PyzMCl}_{2}\right]\left(\mathrm{M}=\mathrm{Pt}^{\mathrm{tI}}, \mathrm{Pd}^{\mathrm{II}}\right)$ and Related Species. Inorg. Chem. 2009, 48, 7086.

90. Donzello M.P., Viola E., Cai X., Mannina L., Ercolani C., Kadish K.M. Tetra-2,3-pyrazinoporphyrazines with Externally Appended Pyridine Rings. 8. Central $\left(\mathrm{Zn}^{\mathrm{II}}, \mathrm{Cu}^{\mathrm{II}}, \mathrm{Mg}^{\mathrm{II}}\left(\mathrm{H}_{2} \mathrm{O}\right)\right.$, $\left.\mathrm{Cd}^{\mathrm{II}}\right)$ and Exocyclic (PdII) Metal ion Binding in Heteropentametallic Complexes from Tetrakis-2,3-[5,6-di(2-pyridyl)pyrazino]porphyrazine. Inorg. Chem. 2010, 49, 2447.

91. Donzello M.P., Vittori D., Viola E., Manet I., Mannina L., Cellai L., Monti S., Ercolani C. Tetra-2,3-pyrazinoporphyrazines with Externally Appended Pyridine Rings. 9. Novel Heterobimetallic Macrocycles and Related Hydrosoluble Hexacations as Potentially Active Photo/Chemotherapeutic Anticancer Agents. Inorg. Chem. 2011, 50, 7391. 
92. Manet I., Manoli F., Donzello M.P., Ercolani C., Vittori D., Cellai L., Masi A., Monti S. Tetra-2,3-pyrazinoporphyrazines with Externally Appended Pyridine Rings. 10. A Water-Soluble Bimetallic $\left(\mathrm{Zn}^{\mathrm{II}} / \mathrm{Pt}^{\mathrm{II}}\right)$ Porphyrazine Hexacation as Potential Plurimodal Agent for Cancer Therapy: Exploring the Behavior as Ligand of Telomeric DNA G-Quadruplex Structures. Inorg. Chem. 2011, 50, 7403.

93. Donzello M.P., Viola E., Mannina L., Fu Z., Ercolani C. Tetra2,3-pyrazinoporphyrazines with Externally Appended Pyridine Rings. 11. Photoactivity of a New $\mathrm{Pt}^{\mathrm{II}}$ Pentanuclear Macrocycle Bearing Four cis-Platin-like Funcionalities and Its Related Monometalated Species. J. Porphyrins Phthalocyanines 2011, in press.

94. Manet I., Manoli F., Donzello M.P., Viola E., Andreano G., Masi A., Cellai L., Monti S. A Cationic $\mathrm{Zn}^{\text {II }}$ Porphyrazine Induces a Stable Parallel G-quadruplex Conformation in
Human Telomeric DNA. Org. Biol. Chem. 2011, 9, 684.

95. Moro P., Donzello M.P., Ercolani C., Monacelli F., Moretti G. Tetrakis-2,3-[5,6-di-(2-pyridyl)-pyrazino]porphyrazine and its $\mathrm{Cu}^{\mathrm{II}}$ Complex as Sensitizers in $\mathrm{TiO}_{2}$-Based Photo-degradation of 4-Nitrophenol. J. Photochem. Photobiol. A, Chemistry 2011, 220, 77

96. Donzello M.P., Viola E., Tomachinskaya L.A., Ercolani C., Corsini M., Zanello P., Stuzhin P.A. Synthesis and Properties of Styryl Substituted Tetrapyrazinoporphyrazines [St ${ }_{8} \mathrm{PyzPzM}$ ] $\left(\mathrm{M}=2 \mathrm{Na}^{\mathrm{I}}, \mathrm{Mg}^{\mathrm{II}}\left(\mathrm{H}_{2} \mathrm{O}\right)\right.$ and $\mathrm{Zn}^{\mathrm{II}}$. J. Porphyrins Phthalocyanines 2010, 14, 793 .

97. De Mori G., Fu Z., Viola E., Cai X., Ercolani C., Donzello M.P., Kadish K.M. Tetra-2,3-pyrazinoporphyrazines with Externally Appended Thienyl Rings: Synthesis, UV-Visible Spectra, Electrochemical Behavior, and Photoactivity for the Generation of Singlet Oxygen. Inorg. Chem. 2011, 50, 8225. 